Slavica

bruxellensia

\section{Slavica bruxellensia}

Revue polyphonique de littérature, culture et histoire

slaves

$6 \mid 2010$

Linguistique russe

\title{
Édito \#6
}

\section{Dorota Walczak}

\section{OpenEdition \\ Journals}

Édition électronique

URL : http://journals.openedition.org/slavica/369

DOI : 10.4000/slavica.369

ISSN : 2034-6395

Éditeur

Université libre de Bruxelles - ULB

\section{Référence électronique}

Dorota Walczak, «Édito \#6 », Slavica bruxellensia [En ligne], 6 | 2010, mis en ligne le 15 juin 2010, consulté le 25 septembre 2020. URL : http://journals.openedition.org/slavica/369 ; DOI : https:// doi.org/10.4000/slavica.369

Ce document a été généré automatiquement le 25 septembre 2020.

\section{(c) $($ ) $(9)$}

Les contenus de Slavica bruxellensia sont mis à disposition selon les termes de la Licence Creative Commons Attribution - Pas d'Utilisation Commerciale - Pas de Modification 3.0 France. 


\section{Édito \#6}

Dorota Walczak 